\title{
The impact of transformational leadership on promoting academic research in higher educational system in Vietnam
}

\author{
Tuan Hung $V_{u^{a}}$, Minh Thu Vu $u^{b}$ and Van Ngoc Hoang ${ }^{c^{*}}$
}

${ }^{a}$ Institute of Regional Sustainable Development (IRSD), Vietnam Academy of Social Sciences, Hanoi, Vietnam

${ }^{b}$ Malaysia University of Science and Technology, Malaysia

${ }^{c}$ Thu Dau Mot university No 6, Tran Van On Street, Thu Dau Mot city, Binh Duong province, Vietnam

CHRONICLE ABSTRACT

Article history:

Received: June 302019

Received in revised format: July

292019

Accepted: September 16, 2019

Available online:

September 18, 2019

Keywords:

Higher education

Academic research

Transformational Leadership

\begin{abstract}
University educational system plays an important role for the development of any country. Most industries normally rely on highly educated people with different skills and the universities are also responsible for training leading edge technology skills. During the past few years, there have been tremendous efforts to empower Vietnamese universities and to put more efforts to increase their ranking internationally. The purpose of this study is to determine the appropriate leadership style on higher education institutions and the role of the leader in promoting academic research at Vietnamese universities. Excellent and effective leadership is needed to develop employees as a sustainable competitive advantage. The leaders of organizations normally have difficulty in speeding up the performance of their followers. Individual performance is studied and evaluated in both scholarly and practical literature. Employee engagement is not only a moderator concept established in organizational theory, but it also offers a variety of views and theories. This paper designs a questionnaire and distributes it among 232 students to measure the effect of transformational leadership in higher educational organizations. Regression analysis is used to measure the effects of different components of transformational leadership on the performance of organizations. The survey results indicate that the Transformational leadership could actually be effective when they are allowed autonomy in organizations, especially on the budget. In summary, the results of the investigation clarify the role and importance of transformational leadership in organizations.
\end{abstract}

\section{Introduction}

Leadership style is a key factor for the success of every organization and it reflects the vision of the leader, influences the staff, and decides to build a strategy to achieve the vision of the organization (Kaplan \& Norton, 2000). Appropriate leadership style will motivate employees to achieve their goals, and even motivate them to work harder to overcome their limits to achieve greater results for the organization (Judge et al., 2002). In addition, leadership style will also help employees improve their satisfaction, engagement and loyalty to the organization (Rossi et al., 2016). Human resources are always considered as a valuable asset of business and society. Today, organizations need not only high-quality human resources, but also desire to promote individual performance of employees (Kaplan \& Norton, 2000). Individual performance is an essential factor for creating a competitive advantage within the organization (Shuck \& Herd, 2012). It also helps to motivate employees to improve individual performance which is always a challenge for leaders. The role of leaders in higher education institutions is not an easy task, so leaders should create links around them (Basham, 2012). When leaders treat their followers as excellent individuals and attract their hopes and desires, a dynamic spiral effect will emerge (Deinert et al., 2015). Employees will contribute more to the organization while their motivation increase, which leads to higher productivity. This can lead to an effort for the organization towards innovation with shared views and commitment to a common vision. Finally, individuals may be linked to complete the task where they may reach a level of synergy in which the whole is bigger than the sum of the parts (Northouse, 2018). This study will focus on investigating the role of Transformational Leadership model in promoting * Corresponding author.

E-mail address: ngochv@tdmu.edu.vn (V.N. Hoang) 
academic research in institutions of higher education in Vietnam. The concept of Transformational Leadership will be analyzed in order to clarify its influence on the performance of each individual (Bass \& Avolio, 1993). In addition, employee engagement will be considered as a moderator variable for the relationship between the transformational leader and an individual performance. The study will also use a case study for more investigation.

The current context of higher education in Vietnam is changing, the role of leaders is expanding, and leaders are facing enormous challenges: globalization, the 4.0 revolution, the competition for quality human resources, government funding for education cuts by public debt and external debt have increased. All of them put pressure on the university leaders. A typical type of leadership in effective leadership will promote innovation and advancement in higher education and academic research. Therefore, an important function of effective leadership is to motivate employees toward academic research productivity (Leopold \& Kaltenecker, 2015). According to Ministry of Education and Training (2018), Vietnam now has nearly 300 universities and colleges but none of them is listed in the top 500 worldwide and top 350 Asia. The problem in this study indicates the importance of the academic research for rating the quality of a university. To reach international academic standards, it is necessary to increase the performance of individuals in higher education institutions. Therefore, the role of leaders will impact to individual performance through the characteristics of leadership. There are different types of leadership such as transformational leadership style, transactional leadership style, etc. (Bass \& Avolio, 1993). In particular, transformational leadership style is the most cited and suggested theory. In recent years, transformational leadership styles have been proposed as an effective leadership style that can transform traditional management practices in the education field to improve team effectiveness (Leopold \& Kaltenecker, 2015). Transformational leadership is defined as the leader who creates positive changes for the followers, while transactional style uses rewards or punishments (Masood et al., 2006).

This research aims to investigate the styles and approaches of transformational leadership, and the leadership behaviors that are relevant to the effectiveness of higher education. The research process consists of two separate tasks, the first is associated with a systematic search on the relevant literature which includes leadership styles related to employee engagement and individual performance in higher education studies. The second element is a series of surveys with scholars who have engaged in leadership research in higher education, or leadership in general.

\section{Method research}

\subsection{The context}

Education is an area that has been focused and developed for over 40 years in Vietnam, especially higher education. Since Vietnam was liberated in 1975, the government has preferred to focus on education to provide human resources collar workers in the period approaching the values of modern technology to rebuild the country, and to bring economic value and property to the country. According to statistics of the Ministry of Education and Training Vietnam (2018), by the end of the school year 2017-2018, the current system has 235 universities and academies (including 170 public establishments, 60 private institutions, and 5 establishments with 100\% foreign capital), 37 scientific research institutes are assigned to provide doctoral education, 33 colleges of pedagogy and two pedagogical secondary colleges.

\subsection{Sample}

Regarding the number of samples, there are many tips for statisticians in choosing the number of samples to study:

The minimum sample size must be greater than 200 samples. Based on the empirical rule, Hair et al. (2006) provided the guide used by the researcher as 5 samples for each observed variable. In this study, 32 observed variables were used, so the sample size must be at least $32 \times 5=160$ samples with $\mathrm{n}>=8 \times \mathrm{m}+50$, where $n$ is the sample size and $m$ is the number of independent variables. In this study there are 6 independent variables, so $n \geq 8 * 6+50=98$ samples. In our study, the sample is 232 .

The research model of the topic is represented by three regression equations as follows:

(1) The regression equation shows the effect of the independent variable on the dependent variable:

Model 1: IP $=\beta_{0}+\beta_{1} \times I A+\beta_{2} \times I B+\beta_{3} \times I M+\beta_{4} \times I S+\beta_{5} \times I C$

(2) The regression equation shows the effect of independent variables and regulatory variables (independent variables) on the dependent variable:

Model 2: $I P=\beta_{0}+\beta_{1} \times I A+\beta_{2} \times I B+\beta_{3} \times I M+\beta_{4} \times I S+\beta_{5} \times I C+\beta_{6} \times E E$

The regression equation shows the effect of the independent variable, moderator variable and interaction variable on the dependent variable:

Model 3: IP $=\beta_{0}+\beta_{1} \times I A+\beta_{2} \times I B+\beta_{3} \times I M+\beta_{4} \times I S+\beta_{5} \times I C+\beta_{6} \times E E++\beta_{7} \times c . I A \times c . E E+\beta_{8} \times c . I B \times c . E E+$ $\beta_{9} \times c . I M \times c . E E+\beta_{10} \times c . I S \times c . E E+\beta_{11} \times c . I C \times c . E E$

where $\beta_{0}$ and $\beta_{\mathrm{i}}$ are regression coefficients, $I A, I B, I M, I S$ and $I C$ are independent variables and $E E$ is a moderator variable.

Finally, $c . I A \times c . E E, c . I B \times c . E E, c . I M \times c . E E, c . I S \times c . E E, c . I C \times c . E E$ is the interaction variable. 


\section{Measure}

The proposed model of this paper uses a questionnaire with 32 questions which are designed to measure five different scales of leadership style as follows,

+ 4 measurement variables: Idealized Influence Attribution (IA);

1. (IA1) IA makes employees feel proud of themselves when they work (Masood et al., 2006).

2. (IA2) Leaders are willing to sacrifice their self-interests for the benefit of the organization (Masood et al., 2006).

3. (IA3) Employees admire and follow when implementing goals (Masood et al., 2006).

4. (IA4) Employees show as people with power and confidence for the members (Northouse, 2018).

+ 4 measurement variables: Idealized Influence Behavior (IB);

1. (IB1) Talk to members about their most important beliefs and values (Bass \& Avolio, 1993).

2. (IB2) Show members the importance of having strong emotions as the determination to perform the task or goal of the project (Bass \& Avolio, 1993).

3. (IB3) Interested in ethical aspects and results of the ethical decisions (Bass \& Avolio, 1993).

4. (IB4) Emphasizes the importance of every individual must be aware of the organization's overall mission Bass \& Avolio, 1993).

+ 4 measurement variables: Inspirational motivation (IM);

1. (IM1) Exchange with the employees optimistically about the future of the organization (Northouse, 2018).

2. (IM2) Communicate in an enthusiastic way to members achieve their goals (Bass \& Avolio, 1993).

3. (IM3) Pointed out to the members see a compelling vision for the future (Bass \& Avolio, 1993).

4. (IM4) Confirm that individual goals and common goals of the organization will be achieved (Hawkins, 2017).

+ 4 measurement variables: Intellectual Stimulation (IS);

1. (IS1) Reassess the assumptions for the issues stated to test its suitability for the target (Hawkins, 2017).

2. (IS2) Encourage employees to seek various solutions in the process of problem-solving (Hawkins, 2017).

3. (IS3) Advising members should look at the issue from a variety of aspects (Hawkins, 2017).

4. (IS4) Introduce new methods, new ideas, creativity for old issues (Hawkins, 2017).

+ 4 measurement variables: Individualized Consideration (IC);

1. (IC1) Provide guidance and feedback to employees for their personal goals and organizational goals (Masood et al., 2006).

2. (IC2) Treating members of the organization equitably, without distinction between upper levels and subordinates or between owners and employees (Masood et al., 2006).

3. (IC3) Attention to the needs, capabilities, and aspirations of each member of the organization (Masood et al., 2006).

4. (IC4) Help employees develop their strengths and overcome their weaknesses with the expectations (Masood et al., 2006).

- 7 measurement variables: Individual Performance Measurement (IP)

1. (EE1) Transformational Leadership styles has an impact on a training, promotions and advancement for employees (Basham, 2012).

2. (EE2) The characteristics of Transformational Leadership styles has an impact on employee engagement (Basham, 2012).

3. (EE3) The effects of Transformational Leadership styles on possitively related to pay satisfaction (Basham, 2012).

4. (EE4) Transformational Leadership create a supportive environment through positive relationship with colleagues in workplace (Basham, 2012).

5. (EE5) Transformational Leadership styles contribute on nature of career for employee engagement (Basham, 2012).

-5 measurement variables: Employee Engagement (EE)

1. (IP1) Each individual has a clear purpose and consistent with the overall goals of the organization (Basham, 2012).

2. (IP2) The role of each individual is assigned a clear (Basham, 2012).

3. (IP3) Individuals are accepted and satisfied about the organization's leadership (Basham, 2012).

4. (IP4) The process of accomplishing the goal creates conditions for the members to think and work together (Basham, 2012).

5. (IP5) The relationship between the members of the organization is always stable through respect, trust and responsibility (Basham, 2012). 
6. (IP6) Communication between employees and leaders are quick, clear, honest and accurate (Basham, 2012).

7. (IP7) Employees achieve common goals set out (Basham, 2012).

To assess the level of response of each respondent, this study used a 5-level Likert scale: Strongly Disagree; Disagree; Neither Agree nor Disagree; Agree; Strongly Agree. In addition, this topic also uses scale identification and scale hierarchy to encrypt information personal characteristics of the respondents (including gender, age, work experience and the organization that the respondent is working).

Research model

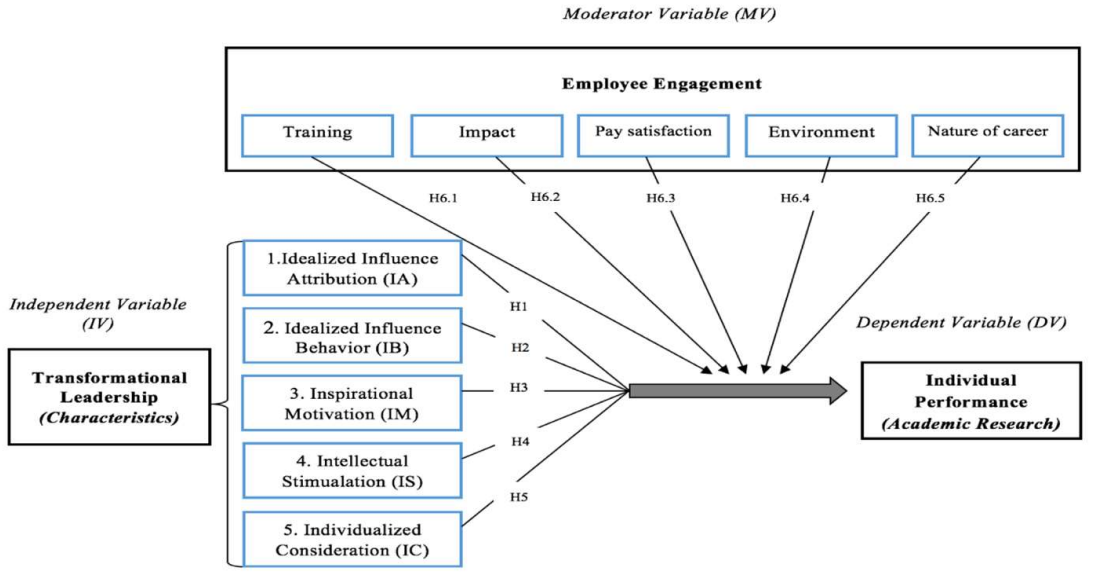

Fig. 1. Hypotheses Framework

From the Hypotheses framework above, this study offers five hypotheses of Transformational Leadership and five hypotheses of Employee Engagement:

$\mathrm{H}_{1}$ : Idealized Influence Attribution (IA) features have positive impacts on individual performance.

$\mathrm{H}_{2}$ : Idealized Influence Behavior (IB) features have positive impacts on individual performance.

$\mathrm{H}_{3}$ : Inspirational Motivation (IM) feature have positive impacts on individual performance.

$\mathrm{H}_{4}$ : Intelectual Stimulation (IS) features have positive impacts on individual performance.

$\mathrm{H}_{5}$ : Individualized Consideration (IC) have positive impacts on individual performance.

The steps in regression analysis MMR:

(1) We assess how the role of the moderator (EE) affects the relationship between independent variables (IA, IB, IM, IS, IC) and the dependent variable (IP) statistically. In addition to determine whether EE plays as moderator variable, regression result (regression coefficient $\beta$, Sig. Significance level) is used.

(2) Graph illustrates the nature of interactive effects

(3) We also examine other assumptions in regression analysis.

\section{Results}

\subsection{Evaluate scale reliability}

Cronbach's Alpha analysis measures the convergence value of observed variables in a scale. The scale is satisfactory when Cronbach's Alpha coefficients are $>0.7$ and correlates the sum of the observed variables $>0.3$. The results of Cronbach Alpha analysis show the observed variable of the Employee engagement scale with low coefficient of total correlation coefficient (less than 0.3), which is EE5 variable (Nature of career: good fit with employees' skills, qualifications and experience, Corrected Item-Total Correlation $=0.279$ ). Therefore, this observed variable is excluded. The results also show that the Cronbach coefficient of Employee engagement is 0.871 and no observed variables has a total marginal correlation coefficient less than 0.3.The end result shows that all scales meet the requirements of Cronbach alpha reliability coefficient: the lowest is .819 (Individualized consideration scale) and the highest is .902 (Intellectual stimulation scale).

\subsection{Exploratory factor analysis (EFA)}

Factor analysis grouped the original observational variables into meaningful new elements, and discovered the underlying structure between the research concepts (initial factor) according to actual data to form new factors are significant to the actual 
research. We see there is correlation between the "Individual performance" as dependent variable with independent variables (1) Idealized Influence Attribution (IA), (2) Idealized Influence behavior (IB), (3) Inspirational motivation (IM), (4) Intellectual stimulation (IS), (5) Individualized consideration (IC). Independent variables: Idealized Influence Attribution, Idealized Influence behavior, Inspirational motivation, Intellectual stimulation, Individualized consideration are positively correlated with the dependent variable and they can be included in the model to explain the Individual performance variable.

\section{Analyzing EFA independent variables}

Table 1

EFA matrix of independent variables

\begin{tabular}{|c|c|c|c|c|c|}
\hline \multirow{2}{*}{ Items } & \multicolumn{5}{|c|}{ Factor } \\
\hline & IS & IA & IM & IC & IB \\
\hline IS4 & .858 & & & & \\
\hline IS3 & .838 & & & & \\
\hline IS1 & .834 & & & & \\
\hline IS2 & .806 & & & & \\
\hline IA1 & & .815 & & & \\
\hline IA3 & & .798 & & & \\
\hline IA2 & & .723 & & & \\
\hline IA4 & & .650 & & & \\
\hline IM1 & & & .919 & & \\
\hline IM3 & & & .773 & & \\
\hline IM4 & & & .622 & & \\
\hline IM2 & & & .568 & & \\
\hline IC4 & & & & .774 & \\
\hline IC3 & & & & .774 & \\
\hline IC2 & & & & .748 & \\
\hline IC1 & & & & 619 & \\
\hline IB2 & & & & & .844 \\
\hline IB4 & & & & & .842 \\
\hline IB1 & & & & & .766 \\
\hline
\end{tabular}

KMO coefficient $=.827$ and Barlett test with Sig. $=.000(<.05)$ show that EFA analysis is appropriate.

Analysis of EFA dependent variables

Table 2

Matrix of factors of Individual Performance scale

\begin{tabular}{ccc}
\hline & \multicolumn{2}{c}{ Factor } \\
\cline { 2 - 3 } Items & Individual Performance \\
\hline IP3 & .719 & .718 \\
IP2 & .710 & .708 \\
IP4 & .707 \\
IP7 & .702 \\
IP1 & .699 \\
\hline IP5 & \\
\hline
\end{tabular}

$\mathrm{KMO}$ coefficient $=.902$ and Barlett test with Sig. $=.000(<.05)$ show that EFA analysis is appropriate.

Table 3

Pearson correlation matrix

\begin{tabular}{|c|c|c|c|c|c|c|c|c|}
\hline & & IA & IB & IM & IS & IC & EE & IP \\
\hline IA & $\begin{array}{l}\text { Pearson Correlation } \\
\text { Sig. (2-tailed) }\end{array}$ & 1 & & & & & & \\
\hline IB & $\begin{array}{l}\text { Pearson Correlation } \\
\text { Sig. (2-tailed) }\end{array}$ & $\begin{array}{c}.409 * * \\
.000\end{array}$ & 1 & & & & & \\
\hline IM & $\begin{array}{l}\text { Pearson Correlation } \\
\text { Sig. (2-tailed) }\end{array}$ & $\begin{array}{c}.371 * * \\
.000\end{array}$ & $\begin{array}{c}.435^{* *} \\
.000\end{array}$ & 1 & & & & \\
\hline IS & $\begin{array}{l}\text { Pearson Correlation } \\
\text { Sig. (2-tailed) }\end{array}$ & $\begin{array}{l}.309 * * \\
.000\end{array}$ & $\begin{array}{c}.473 * * \\
.000\end{array}$ & $\begin{array}{c}.443 * * \\
.000\end{array}$ & 1 & & & \\
\hline IC & $\begin{array}{l}\text { Pearson Correlation } \\
\text { Sig. (2-tailed) }\end{array}$ & $\begin{array}{l}.319^{* *} \\
.000\end{array}$ & $\begin{array}{l}.422 * * \\
.000\end{array}$ & $\begin{array}{c}.448 * * \\
.000\end{array}$ & $\begin{array}{l}.418^{* *} \\
.000\end{array}$ & 1 & & \\
\hline $\mathrm{EE}$ & $\begin{array}{l}\text { Pearson Correlation } \\
\text { Sig. (2-tailed) }\end{array}$ & $\begin{array}{c}.264 * * \\
.000\end{array}$ & $\begin{array}{l}.331 * * \\
.000\end{array}$ & $\begin{array}{l}.302 * * \\
.000\end{array}$ & $\begin{array}{l}.401 * * \\
.000\end{array}$ & $\begin{array}{l}.338^{* *} \\
.000\end{array}$ & 1 & \\
\hline IP & $\begin{array}{l}\text { Pearson Correlation } \\
\text { Sig. (2-tailed) }\end{array}$ & $\begin{array}{l}.585^{* *} \\
.000\end{array}$ & $\begin{array}{l}.478 * * \\
.000\end{array}$ & $\begin{array}{c}.486 * * \\
.000\end{array}$ & $\begin{array}{l}.500 * * \\
.000\end{array}$ & $\begin{array}{l}.492 * * \\
.000\end{array}$ & $\begin{array}{l}.325^{* *} \\
.000\end{array}$ & 1 \\
\hline
\end{tabular}

\subsection{Testing the relevance of the model}

In this analysis, to evaluate the appropriateness of the model, a coefficient of $\mathrm{R}^{2}$ or Adjusted- $\mathrm{R}^{2}$ is used; These two values represent the suitability of the model. Based on the adjustment coefficient $\mathrm{R}^{2}$ adj in the regression summary model, we in turn analyze and compare the explanatory level of models 1,2 and 3 as follows: 
Table 4

Summary model

\begin{tabular}{|c|c|c|c|c|c|c|c|c|c|c|}
\hline \multirow[b]{2}{*}{ Model } & \multirow[b]{2}{*}{$\mathrm{R}$} & \multirow[b]{2}{*}{ R Square } & \multirow[b]{2}{*}{$\begin{array}{l}\text { Adjusted R } \\
\text { Square }\end{array}$} & \multirow[b]{2}{*}{ SE } & \multicolumn{5}{|c|}{ Change Statistics } & \multirow[b]{2}{*}{$\begin{array}{l}\text { Durbin- } \\
\text { Watson }\end{array}$} \\
\hline & & & & & $\begin{array}{l}\text { R Square } \\
\text { Change }\end{array}$ & F Change & df1 & df 2 & $\begin{array}{c}\text { Sig. F } \\
\text { Change }\end{array}$ & \\
\hline 1 & $.723 a$ & .522 & .517 & .55773 & .522 & 107.982 & 5 & 494 & .000 & \\
\hline 2 & $.723 b$ & .522 & .517 & .55822 & .000 & .134 & 1 & 493 & .714 & 1.791 \\
\hline 3 & $.747 \mathrm{c}$ & .558 & .548 & .53969 & .036 & 7.886 & 5 & 488 & .000 & \\
\hline
\end{tabular}

As we can observe from the results of Table 4, Durbin-Watson is equal to 1.791 and it is within the desirable level. Therefore, we can conclude that there is no autocorrelation among residuals. Moreover, Table 5 shows the results of ANOVA test. The results have indicated that F-value has desirable value and there is a linear relationship between independent variable and dependent variables.

Table 5

Evaluation results of the suitability of the model

\begin{tabular}{|c|c|c|c|c|c|c|}
\hline & Model & Sum of Squares & $\mathrm{df}$ & Mean Square & $\mathrm{F}$ & Sig. \\
\hline \multirow[t]{3}{*}{1} & Regression & 167.944 & 5 & 33.589 & 107.982 & $.000 \mathrm{~b}$ \\
\hline & Residual & 153.663 & 494 & .311 & & \\
\hline & Total & 321.607 & 499 & & & \\
\hline \multirow[t]{3}{*}{2} & Regression & 167.986 & 6 & 27.998 & 89.850 & $.000 \mathrm{c}$ \\
\hline & Residual & 153.621 & 493 & .312 & & \\
\hline & Total & 321.607 & 499 & & & \\
\hline \multirow[t]{3}{*}{3} & Regression & 179.470 & 11 & 16.315 & 56.016 & $.000 \mathrm{~d}$ \\
\hline & Residual & 142.137 & 488 & .291 & & \\
\hline & Total & 321.607 & 499 & & & \\
\hline
\end{tabular}

Table 6

Hierarchical regression results

\begin{tabular}{|c|c|c|c|c|}
\hline \multirow{2}{*}{ No } & \multirow{2}{*}{ Criteria } & Model 1 & Model 2 & Model 3 \\
\hline & & Beta & Beta & Beta \\
\hline 1 & Idealized Influence Attribution (IA) & $0.376^{* *}$ & $0.375^{* *}$ & $0.352 * *$ \\
\hline 2 & Idealized Influence behavior (IB) & $0.091 *$ & $0.090^{*}$ & $0.105^{*}$ \\
\hline 3 & Inspirational motivation (IM) & $0.132 *$ & $0.131 *$ & $0.153 * *$ \\
\hline 4 & Intellectual stimulation (IS) & $0.203 * *$ & $0.200 * *$ & $0.203 * *$ \\
\hline 5 & Individualized consideration (IC) & $0.190 * *$ & $0.188 * *$ & $0.198 * *$ \\
\hline 6 & Employee engagement (EE) & & .013 & .062 \\
\hline 7 & $\mathrm{IA}^{*} \mathrm{EE}$ & & & .000 \\
\hline 8 & IB*EE & & & $0.091 *$ \\
\hline 9 & $\mathrm{IM}^{*} \mathrm{EE}$ & & & $0.104 *$ \\
\hline 10 & IS*EE & & & .006 \\
\hline \multirow[t]{7}{*}{11} & $\mathrm{IC}^{*} \mathrm{EE}$ & & & .025 \\
\hline & $\mathrm{R} 2$ & 0.522 & 0.522 & 0.558 \\
\hline & R2 adj & 0.517 & 0.517 & 0.548 \\
\hline & $\mathrm{R} 2$ & & 0 & 0.036 \\
\hline & R2 adj & & 0 & 0.031 \\
\hline & $\mathrm{F}$ or $\mathrm{F}$ change & 107.982 & .134 & 7.886 \\
\hline & Sig. F change & 0.000 & 0.714 & 0.000 \\
\hline
\end{tabular}

Model 1: The regression statistics results of model 1 show the independent variables IA, IB, IM, IS and IC positively impact the IP (Individual performance) at the 5\% significance level. The standardized regression weights of independent variables have the same values as: $\beta_{\mathrm{IA}}=0.376, \beta_{\mathrm{IB}}=0.091, \beta_{\mathrm{IM}}=0.132, \beta_{\mathrm{IS}}=0203, \beta_{\mathrm{IC}}=0.190$.

In the above coefficients, the IA (Idealized Influence Attribution) has the most IP impact (Individual performance).

Model 2: The results of regression weight statistics of model 2 show the independent variables IA, IB, IM, IS and IC positively impact the IP (Individual performance) at the 5\% significance level. The standardized regression weights of the independent variables are measured in turn: $\beta_{\mathrm{IA}}=0.375, \beta_{\mathrm{IB}}=0.090, \beta_{\mathrm{IM}}=0.131, \beta_{\mathrm{IS}}=0200, \beta_{\mathrm{IC}}=0.188$. EE variable does not act as an independent variable.

Model 3: The results of regression weight statistics of model 3 show that independent variables IA, IB, IM, IS, IC have a positive impact on the IP variable (Individual Performance) at the 5\% significance level. The standardized regression weights of the independent variables with values are respectively: $\beta_{\mathrm{IA}}=0.352, \beta_{\mathrm{IB}}=0.105, \beta_{\mathrm{IM}}=0.153, \beta_{\mathrm{IS}}=0203, \beta_{\mathrm{IC}}=0.198$. Own EE variable has sig. $=0.094>5 \%$ has no significant impact on IP variables.

The interaction variables c.IA.EE, c.IC.EE, c.IS.EE do not reach the significance level (because Sig is equal to $>0.05$ ) to conclude the impact on the IP variable. Interactive variable c.IB.EE has sig. $=0.042$ and c.IM.EE has sig. $=0.037<5 \%$. Therefore, EE variable plays the role of moderator in the relationship between IB and IP, IM and IP. The results show that 
Idealized influence behavior and Inspirational motivation increase with the difference in employee engagement. As the difference in employee engagement among employees increases, the relationship between Idealized influence behavior and individual performance, between Inspirational motivation and individual performance increases. In other words, Employee engagement strengthens the relationship between Idealized influence behavior and Individual Performance and Employee engagement strengthens the relationship between Inspirational motivation and Individual Performance (Fig. 2).
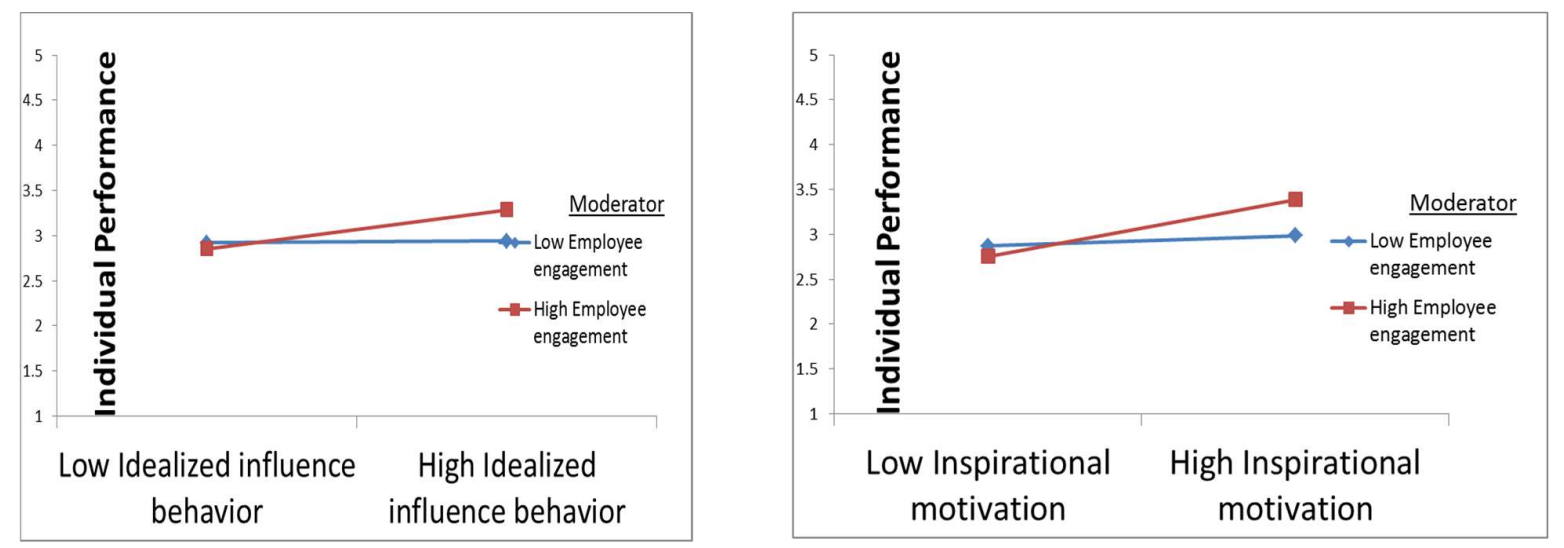

Fig. 2. Moderate of employee engagement

\section{Conclusion}

The study has presented and discussed the analytical results to address research objectives and research questions. The characteristics of independent variables and dependent variables were also described and explained in details. Through research findings from survey questionnaire answers show that Transformational leadership plays an important role for the success of the organizations. There are many requirements to adopt Transformational leadership in personality traits, however, this leadership style is appropriate to the context of higher education in advanced countries by giving high efficiency. These characteristics will shape their role in the organization in promoting and encouraging employees to focus and develop academic study. The survey results have also shown that participants were fully satisfied with the policies of their leaders and this is an important factor in promoting this kind of leadership. The survey results have also emphasized that the Transformational leadership will actually be effective when the leaders have been allowed autonomy in organizations, especially on the budget. In summary, the results of the investigation clarified the role and the importance of the impact of the Transformational leadership in organizations.

\section{Acknowledgement}

The authors would like to thank the anonymous referees for constructive comments on earlier version of this paper.

\section{References}

Barbuto, J. E., \& Burbach, M. E. (2006). The emotional intelligence of transformational leaders: A field study of elected officials. The Journal of Social Psychology, 146(1), 51-64.

Basham, L. M. (2012). Transformational and transactional leaders in higher education. SAM Advanced Management Journal, 77(2), 15 .

Bass, B. M., \& Avolio, B. J. (1993). Transformational leadership: A response to critiques.

Deinert, A., Homan, A. C., Boer, D., Voelpel, S. C., \& Gutermann, D. (2015). Transformational leadership sub-dimensions and their link to leaders' personality and performance. The Leadership Quarterly, 26(6), 1095-1120.

Hair Jr, J. F. (2006). Black, Wc, Babin, Bj Anderson, Re \& Tatham, R1 (2006). Multivariate data analysis, 6.

Hawkins, P. (2017). Leadership team coaching: Developing collective transformational leadership. Kogan Page Publishers.

Judge, T. A., Bono, J. E., Ilies, R., \& Gerhardt, M. W. (2002). Personality and leadership: a qualitative and quantitative review. Journal of applied psychology, 87(4), 765.

Kaplan, R. S., \& Norton, D. P. (2000). Having trouble with your strategy? Then map it. Focusing Your Organization on Strategy-with the Balanced Scorecard, 49.

Leopold, K., \& Kaltenecker, S. (2015). Kanban change leadership: Creating a culture of continuous improvement. John Wiley \& Sons.

Masood, S. A., Dani, S. S., Burns, N. D., \& Backhouse, C. J. (2006). Transformational leadership and organizational culture: the situational strength perspective. Proceedings of the Institution of Mechanical Engineers, Part B: Journal of Engineering Manufacture, 220(6), 941-949.

Northouse, P. G. (2018). Leadership: Theory and practice. Sage publications.

Rossi, D., Gacenga, F., \& Danaher, P. A. (Eds.). (2016). Navigating the Education Research Maze: Contextual, Conceptual, 
Methodological and Transformational Challenges and Opportunities for Researchers. Springer.

Shuck, B., \& Herd, A. M. (2012). Employee engagement and leadership: Exploring the convergence of two frameworks and implications for leadership development in HRD. Human resource development review, 11(2), 156-181.

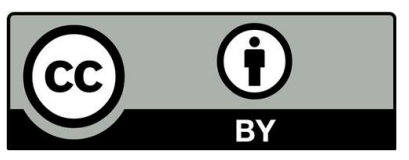

(C) 2020 by the authors; licensee Growing Science, Canada. This is an open access article distributed under the terms and conditions of the Creative Commons Attribution (CCBY) license (http://creativecommons.org/licenses/by/4.0/). 